Original Research Article

\title{
Antidiabetic activity of Coriandrum sativum in streptozotocin induced diabetic rats
}

\author{
Sayan Das, Sanjeevani Chaware*, Nimish Narkar, Abhijeet V. Tilak, \\ Siddhi Raveendran, Pratik Rane
}

Department of Pharmacology, D.Y. Patil Medical College and Hospital, Pune, Maharashtra, India

Received: 07 February 2019

Revised: 21 March 2019

Accepted: 06 April 2019

*Correspondence to:

Dr. Sanjeevani Chaware, Email: dr.sanjeevani1802@ gmail.com

Copyright: () the author(s), publisher and licensee Medip Academy. This is an openaccess article distributed under the terms of the Creative Commons Attribution NonCommercial License, which permits unrestricted noncommercial use, distribution, and reproduction in any medium, provided the original work is properly cited.

\begin{abstract}
Background: Diabetes mellitus (DM) can be defined as chronic hyperglycemia due to lack in insulin secretion and/or action. This study was designed to compare the antidiabetic activity of Coriandrum sativum L. with the standard antidiabetic drug, Metformin in Streptozotocin induced diabetic rats.

Methods: Streptozotocin (STZ) was used to induce diabetes in the rats. Standard drug was metformin and test drug were Coriandrum sativum seed extract. 4 groups of 8 rats each were taken (normal control, diabetic control, streptozotocin + Coriandrum sativum and streptozotocin + metformin). Blood Sugar Levels (BSL) and $\mathrm{HbA}_{1 \mathrm{C}}$ levels were estimated on day 0, 14 and 28 and day 28 respectively.

Results: Streptozotocin administration resulted in significant rise in BSL. This rise was reduced with the administration of $C S$ seed extract, but the reduction was more with chronic administration. It also reduced the $\mathrm{HbA}_{1 \mathrm{C}}$ levels but couldn't attain total normoglycemia. However, the reduction of BSL was superior with Metformin compared to the test drug.

Conclusions: Oral administration of Coriandrum sativum seed extract at a dose of $40 \mathrm{mg} / \mathrm{kg}$ has shown antihyperglycemic activity in streptozotocin induced diabetic rats. Thus, Coriandrum sativum may have considerable therapeutic benefit as an antidiabetic agent and can be suggested as a potential dietary add on.
\end{abstract}

Keywords: BSL, Coriandrum sativum, Diabetes, $\mathrm{HbA}_{1 \mathrm{C}}$, Metformin, T2DM

\section{INTRODUCTION}

Diabetes mellitus can be defined as chronic hyperglycemia along with disturbances of carbohydrate, protein \& fat metabolism resulting from lack in insulin secretion, action or both. ${ }^{1}$

According to the International Diabetes Federation (IDF), diabetes mellitus is one of the chief causes of morbidity and mortality worldwide. ${ }^{2}$ India has the world's second largest diabetes population. . $^{3,4}$
Oral hypoglycemic agents are usually the first line of drug treatment for type 2 diabetes mellitus (T2DM). Overall metformin is the most preferred prescribed anti diabetic agent followed by sulphonylureas, thiazolidinediones, $\alpha-$ glucosidase inhibitors and dipeptidyl peptidase 4 inhibitors. Metformin along with sulphonylureas is the most preferred combination therapy. A combination of two or more group of the drugs is usually required in order to achieve optimal blood glucose levels. ${ }^{5}$ However, each class of drugs has some limitations. Hence, the search for safer and more effective antidiabetic drug has continued to 
achieve better normoglycemia and to prevent long term complications.

For the treatment of diabetes mellitus, the use of ayurvedic or herbal medicines has been on a rise throughout the world. The World Health Organization (WHO) also recommended and encouraged the practice especially in countries where access to the conventional treatment of diabetes is not adequate. ${ }^{6}$ The available literature shows that the hypoglycemic activity of some herbal extracts such as Aloe vera, Coccinia indica, Gymnema sylvestre and Trigonella foenum has been confirmed in animal models of type 2 diabetes and some clinical trials. ${ }^{7}$

Coriandrum sativum Linn. (Apiaceae), commonly known as coriander, cilantro, and dhania is an annual herb commonly used in ayurvedic medicine and also in cuisine in Middle East, Latin America and Asia. ${ }^{8}$ Pharmacological studies have demonstrated possible hypoglycemic, hypolipidemic, antihypertensive, anti-inflammatory, anxiolytic, antimicrobial, diuretic and cognition improvement activities in experimental animals. ${ }^{9,10}$

This study is designed to compare the antidiabetic effect of Coriandrum sativum L. with the standard antidiabetic drug, metformin in streptozotocin induced diabetic rats. With the following objectives:

- To study the antidiabetic activity of Coriandrum sativum.

- To compare the antidiabetic activity of Coriandrum sativum with metformin.

\section{METHODS}

Institutional Animal Ethics Committee (IAEC) clearance was obtained before start of the study.

Total 32 experimentally inexperienced study animals were acquired from the animal house of Dr. D.Y. Patil Medical College, Pimpri, Pune. Sprague-Dawley rats of Rattus norvegicus species (either sex weighing 100 - 200 g) were selected for the study and were fed with commercially available 'Nutrimix Std-1020'and water ad libitum.

Aqueous extract of Coriandrum sativum seeds was used for this study. The seeds were obtained from the local market, and then verification and extraction of aqueous form was done by Dr. D. Y. Patil College of Ayurveda and Research Centre, Pimpri, Pune. Dose of $40 \mathrm{mg} / \mathrm{kg}$ body weight per orally was used. ${ }^{9}$

Metformin was used as the standard drug in the dose of 90 $\mathrm{mg} / \mathrm{kg}$ body weight per orally. ${ }^{11}$ Both the drugs were administered orally once daily for 28 days. Streptozotocin (STZ) was used to induce diabetes in the rats at $40 \mathrm{mg} / \mathrm{kg}$ single intra-peritoneal (i.p.) dose. ${ }^{12}$ Blood sample was taken from the animals after 3 days and fasting blood sugar levels were checked by using a glucometer. Rats having blood sugar levels above $180 \mathrm{mg} / \mathrm{dl}$ were included in the study.

The rats were divided into following groups. Each group had 8 rats distributed randomly ( $n=8$ in each group).

\section{Parameters}

Fasting blood sugar levels (BSL-F) were measured on baseline ( $3^{\text {rd }}$ day after i.p. injection of streptozotocin), $14^{\text {th }}$ and $28^{\text {th }}$ day of all the groups.

The glycated hemoglobin $\left(\mathrm{HbA}_{1 \mathrm{C}}\right)$ level was measured according to the standard protocol on $28^{\text {th }}$ day from blood sample collected from retro-orbital space.

Table 1: Groups of rats.

\begin{tabular}{|c|c|c|}
\hline Group & Type & Dose \\
\hline Group 1 & Normal control & $\begin{array}{l}\text { Distilled water (p.o.) } \\
10 \mathrm{ml} / \mathrm{kg}\end{array}$ \\
\hline Group 2 & Diabetic control & $\begin{array}{l}\text { Streptozotocin (i.p.) } \\
40 \mathrm{mg} / \mathrm{kg}\end{array}$ \\
\hline Group 3 & $\begin{array}{l}\text { Streptozotocin + } \\
\text { Coriandrum } \\
\text { sativum }\end{array}$ & $\begin{array}{l}\text { Streptozotocin (i.p.) } \\
\text { 40mg/kg }+ \\
\text { Coriandrum sativum } \\
\text { (p.o.) } 40 \mathrm{mg} / \mathrm{kg}\end{array}$ \\
\hline Group 4 & $\begin{array}{l}\text { Streptozotocin }+ \\
\text { Metformin }\end{array}$ & $\begin{array}{l}\text { Streptozotocin (i.p.) } \\
40 \mathrm{mg} / \mathrm{kg}+ \\
\text { Metformin (p.o.) } 90 \\
\mathrm{mg} / \mathrm{kg}\end{array}$ \\
\hline
\end{tabular}

\section{Statistical analysis}

The data was compiled and analysed by using the statistical package, Primer of Biostatistics 7.0. Results are expressed as Mean \pm SD. and statistical significance between means was analyzed using one-way analysis of variance (ANOVA) followed by Tukey's multiple comparison test. $\mathrm{p}$ value $<0.05$ was considered as statistically significant.

\section{RESULTS}

As per the methods, the study was carried out in 4 different groups. The results are expressed as mean $\pm \mathrm{SD}$.

\section{Induction of diabetes}

As shown in Table 2, there was significant increase in BSL$\mathrm{F}$ on $3^{\text {rd }}$ day after injection of STZ for groups 2,3 , and 4 when compared to group 1 which was statistically significant $(\mathrm{p}<0.05)$ thus implying that diabetes was induced.

As seen from Table 3, the mean BSL values were higher on $28^{\text {th }}$ day compared to $14^{\text {th }}$ day in group 2 suggesting a deteriorating diabetes control. Metformin has reduced 
blood sugar levels and has significant statistical difference from group $2(\mathrm{p}<0.05)$.

The rise in BSL with STZ was comparatively reduced in group 4 on both $14^{\text {th }}$ day $(\mathrm{p}<0.05)$ and on 28 th day ( $<0.05)$ when compared to group 2 , but the reduction was more on chronic administration for a longer time, i.e. $28^{\text {th }}$ day which is also statistically significant $(\mathrm{p}<0.05)$.

However, the mean BSL-F of group 3 was much lower and statistically significant when compared to group 4 on both $14^{\text {th }}$ and $28^{\text {th }}$ day $(\mathrm{p}<0.05)$. Thus, suggesting that the antihyperglycemic activity of Coriandrum sativum seed extract is lesser than metformin.
Table 2: Mean fasting blood sugar levels after induction of diabetes.

\begin{tabular}{|lll|}
\hline Group & Treatment & $\begin{array}{l}\text { BSL-F at baseline } \\
(\mathbf{m g} / \mathbf{d l}) \text { Mean } \pm \text { S.D. }\end{array}$ \\
\hline 1 & Control & $97.12 \pm 3.87$ \\
\hline 2 & Diabetic control & $343.20 \pm 30.25^{*}$ \\
\hline 3 & $\begin{array}{l}\text { Metformin } 90 \\
\mathrm{mg} / \mathrm{kg}\end{array}$ & $351.00 \pm 27.59^{*}$ \\
\hline 4 & $\begin{array}{l}\text { Coriandrum } \\
\text { sativum } 40 \mathrm{mg} / \mathrm{kg}\end{array}$ & $345.40 \pm 29.06^{*}$ \\
\hline
\end{tabular}

$* \mathrm{p}<0.05$ : compared to group 1 .

Table 3: Effect on fasting blood sugar levels (BSL-F).

\begin{tabular}{|llll|}
\hline Group & Treatment & $\begin{array}{l}\text { BSL-F on } \mathbf{1 4}^{\text {th }} \text { day }(\mathbf{m g} / \mathbf{d l}) \\
\text { Mean } \pm \text { S.D. }\end{array}$ & $\begin{array}{l}\text { BSL-F on 28 } \\
\text { Mean } \pm \text { S.D. }\end{array}$ \\
\hline 1 & Control & $99.63 \pm 4.69$ & $99.75 \pm 4.65$ \\
\hline 2 & Diabetic control & $374.00 \pm 35.73$ & $402.88 \pm 30.77$ \\
\hline 3 & Metformin $90 \mathrm{mg} / \mathrm{kg}$ & $255.25 \pm 21.82^{*}$ & $155.25 \pm 15.72^{*}$ \\
\hline 4 & Coriandrum sativum $40 \mathrm{mg} / \mathrm{kg}$ & $298.00 \pm 25.89 * \#$ & $203.88 \pm 14.69^{*} \#$ \\
\hline
\end{tabular}

$* \mathrm{p}<0.05$ : compared to group 2; \#p <0.05: compared to group 3

\section{Effect on glycated hemoglobin $\left(\mathrm{HbA}_{1 \mathrm{C}}\right)$}

The mean $\mathrm{HbA}_{1 \mathrm{C}}$ levels on $28^{\text {th }}$ day of group 1 was $5.82 \pm 0.21 \%$ which was in the normal range as expected and had significant statistical difference with group 2 which had a mean $\mathrm{HbA}_{1 \mathrm{C}}$ level of $12.93 \pm 1.16$, as $\mathrm{p} 0.05$, showing that there was chronic poor control of BSL among the diabetic rats.

Table 4: Effect on mean glycated hemoglobin $\left(\mathrm{HbA}_{1 \mathrm{C}}\right)$ levels on $28^{\text {th }}$ day.

\begin{tabular}{|lll|}
\hline Group & Treatment & $\begin{array}{l}\text { HbA } 1 \text { on 28th day }(\%) \\
\text { Mean } \pm \text { S.D. }\end{array}$ \\
\hline 1 & Control & $5.82 \pm 0.21$ \\
\hline 2 & Diabetic control & $12.93 \pm 1.16$ \\
\hline 3 & $\begin{array}{l}\text { Metformin } 90 \\
\mathrm{mg} / \mathrm{kg}\end{array}$ & $6.98 \pm 0.56^{*}$ \\
\hline 4 & $\begin{array}{l}\text { Coriandrum } \\
\text { sativum } 40 \mathrm{mg} / \mathrm{kg}\end{array}$ & $8.63 \pm 0.49 * \#$ \\
\hline * $\mathrm{p}<0.05:$ compared to group $2 ; \# \mathrm{p}<0.05:$ compared to group
\end{tabular}
3.

As seen from the Table 4, the test drug Coriandrum sativum seed extract $40 \mathrm{mg} / \mathrm{kg}$ (group 4) reduced the mean $\mathrm{HbA}_{1 \mathrm{C}}$ levels on $28^{\text {th }}$ day in comparison to group 2, which was also statistically significant $(p<0.05)$ which proves that there was good control of BSL among group 4 in comparison to group 2 . The mean $\mathrm{HbA}_{1 \mathrm{C}}$ levels of group 3 on $28^{\text {th }}$ day showed significant reduction compared to group 2. However, group 3 showed better results in comparison to group 4, which was also statistically significant $(\mathrm{p}<0.05)$.

\section{DISCUSSION}

Diabetes mellitus (DM) is a huge healthcare burden in not just the developed countries but also in developing countries including India. ${ }^{13}$

Also, the cost of treatment is not affordable to many patients in developing countries as treatment required is for life long. In such a scenario, use of alternative medicine such as herbal medicine can play an important role, as these drugs are comparatively safer and have low cost. The discovery of metformin (biguanides) was traced to a plant i.e., Galega officinalis. ${ }^{14}$ Plant materials which are being used as traditional medicine for the treatment of diabetes are considered one of the good sources for a new drug or a lead to make a new drug. Plant extract or different folk plant preparations are being prescribed by the traditional practitioners and also accepted by the patients especially in third world countries. Therefore, proper scientific evaluations and screening of plants by pharmacological tests followed by chemical investigations are necessary. ${ }^{15}$

On the other hand, appropriate nutritional management is essential for restoring and maintaining a normal metabolic state. Therefore, diet remains a cornerstone in diabetes management. Coriandrum sativum locally known as kothimbir or dhania in Hindi, is a part of everyday diet and its seeds also are a regular part, as spices in daily diet. 
Oral administration of Coriandrum sativum seed extract 40 $\mathrm{mg} / \mathrm{kg}$ was associated with significant lowering of BSL and $\mathrm{HbA}_{1 \mathrm{C}}$ levels compared to diabetic control group of rats (group 2) $(\mathrm{p}<0.05)$. However, the antidiabetic effect of metformin was much superior to Coriandrum sativum seed extract and was statistically significant too, thus suggesting that metformin is a more potent antidiabetic agent in comparison to Coriandrum sativum seed extract.

Present study findings are in agreement with other studies from literature. Aissaoui A et al, had also shown that sub chronic administration of Coriandrum sativum seed extract exhibited significant reduction in serum glucose in both normal and obese-hyperglycemic-hyperlipidemic (OHH) Meriones shawi rats. ${ }^{9}$

Gray AM et al, demonstrated the presence of antihyperglycemic, insulin-releasing and insulin-like activity in Coriandrum sativum. ${ }^{16}$ While, Eidi $\mathrm{M}$ et al, (2009) pointed out that ethanol extract of coriander seed exhibited a significant reduction of BSL in STZ induced diabetic fasted male wistar rats. ${ }^{17}$

Sreelatha $\mathrm{S}$ et al, demonstrated that both Coriandrum sativum leaves and stems possess a significant hypoglycemic effect. ${ }^{10}$ Naquvi KJ et al, concluded that high dose of Coriandrum sativum fruits significantly reduced the BSL. ${ }^{18}$ While Brindis $\mathrm{F}$ et al, demonstrated that the hypoglycemic effect of leaf's extract is lower than the effect of seed's extract. ${ }^{19}$

Whereas Jelodar G et al, stated that coriander leaf did not exert significant hypoglycemic effect in alloxan induced diabetic rats. $^{20}$

A clinical study was also conducted by Waheed A et al, in Pakistan on T2DM patients and concluded that the significant hypoglycemic activity of Coriandrum sativum seeds in high doses was found to be effective as an add on drug in uncontrolled T2DM patients. ${ }^{21}$ Similar clinical study was done by Rajeshwari U et al, that showed a sharp reduction of $13 \%$ in blood glucose levels. ${ }^{22}$

The mechanism of antihyperglycemic activity of the Coriandrum sativum seed extract may be due to a number of different pathways. It can be due to stimulation of glucose utilization by peripheral tissues, by enhancement of insulin sensitivity or increase in hepatic glucose uptake, or by decrease in hepatic glucose production, as suggested by Gray AM et al. ${ }^{16}$

Inhibition of $\alpha$-glucosidase activity in the gastrointestinal tract can be another probable mechanism of action as suggested by Brindis $\mathrm{F}$ et al. ${ }^{19}$ Inhibition of glucose diffusion or absorption across the gastrointestinal tract in vitro possibly by inhibition of intestinal nutrient transporters such as intestinal $\mathrm{Na}^{+}$-dependent glucose transporter 1 (SGLT1) can also be another mechanism of action as reported by Gallagher AM et al. ${ }^{23}$
Due to the long history of safe ingestion offresh leaves and the dried seeds in most of the traditional cooking, this can be considered as a safe alternative.

As most of the antidiabetic drugs are associated with side effects and high cost, Coriandrum sativum seed extract as an antidiabetic agent can be used as an add on drug or as a diet supplement thus reducing blood glucose levels.

Thus, Coriandrum sativum seed extract can play an important role in the management of diabetes especially in developing countries like India where access to specialised treatment facilities are limited.

\section{CONCLUSION}

Oral administration of Coriandrum sativum seed extract at a dose of $40 \mathrm{mg} / \mathrm{kg}$ has shown antihyperglycemic activity in streptozotocin induced diabetic rats. Thus, Coriandrum sativum may have considerable therapeutic benefit as an antidiabetic agent and can be suggested as a potential dietary add on.

Funding: No funding sources

Conflict of interest: None declared

Ethical approval: The study was approved by the Institutional Ethics Committee

\section{REFERENCES}

1. Kahn CR, Weir GC, King GL, Moses AC, Smith RJ, Jacobson AM, editors. Joslin's Diabetes Mellitus 14th ed. Boston: Joslin Diabetes Center; 2005.

2. Ramachandran A. Socio-economic burden of diabetes in India. J Assoc Physicians India. 2007;55(L):9.

3. Cho NH, Whiting D, Forouhi N, Guariguata L, Li R,Narayan V. IDF Diabetes Atlas [e-book]. 7th ed. Brussels(Bel): International Diabetes Federation; 2015. Available at: http://www.idf.org/diabetesatlas. Accessed 29 January 2017.

4. King H, Aubert RE, Herman WH. Global burden of diabetes, 1995-2025: prevalence, numerical estimates, and projections. Diab Care. 1998;21(9):1414-31.

5. Das S, Tilak AV, Narkar N, Dange SV, Rane BT, Shende SS. Prescription preference of antidiabetic drugs among clinicians. Pharma Innovation J. 2019;8(3):59-63.

6. WHO expert committee on diabetes mellitus Technical report series 646. 2nd report, World Health Organization, Geneva, 1980:1-80. Available at: https://apps.who.int/iris/handle/10665/41399.

7. Yeh GY, Eisenberg DM, Kaptchuk TJ, Phillips RS. Systematic review of herbs and dietary supplements for glycemic control in diabetes. Diab Care. 2003:26:1277-94.

8. Sahib NG, Anwar F, Gilani AH, Hamid AA, Saari N, Alkharfy KM. Coriander (Coriandrum sativum L.): a potential source of high-value components for functional foods and neutraceuticals: a review. Phytother Res. 2013;27:1439-56. 
9. Aissaoui A, Zizi S, Israili ZH, Lyoussi B. Hypoglycemic and hypolipidemic effects of Coriandrum sativum L. in Meriones shawi rats. J Ethnopharmacol. 2011;137(1):652-61.

10. Sreelatha S, Inbavalli R. Antioxidant, antihyperglycemic, and antihyperlipidemic effects of Coriandrum sativum leaf and stem in alloxan-induced diabetic rats. J Food Sci. 2012;77:119-23.

11. Ghosh MN. Fundamentals of Experimental Pharmacology. 6th ed. Kolkata: Hilton \& Company; 2015:173.

12. Akbarzadeh A, Norouzian D, Mehrabi MR, Jamshidi S, Farhangi A, Verdi AA, et al. Induction of diabetes By Streptozotocin in Rats. Indian J Clin Biochem. 2007;22(2):60-4.

13. Lorenzi GM, LaRue SM, Collins SE. Effects of a patient education support program on pramlitinide adherence. Clin Diab. 2011;29(1):17-24.

14. Bailey C, Day C. Metformin: its botanical background. Practical Diab Int. 2004;21(3):115-7.

15. Wadkar KA, Magdum CS, PAtil SS, Naikwade NS. Antidiabetic potential and Indian medicinal plants. J Herbal Med Toxicol. 2008;2(1):45-50.

16. Gray AM, Flatt PR. Insulin-releasing and insulin like activity of the traditional anti-diabetic plant Coriandrum sativum (Coriander). $\mathrm{Br} \quad \mathrm{J}$ Nutr. 1999;81(3):203-209.

17. Eidi M, Eidi A, Saedi A, et al. Effect of coriander seed (Coriandrum sativum L.) ethanol extract on insulin release from pancreatic beta cells in streptozotocininduced diabetic rats. Phytoter Res. 2009;23(3):404-6.

18. Naquvi KJ, Ali M, Ahamad J. Antidiabetic activity of aqueous extract of Coriandrum sativum fruits in streptozotocin induced rats. Int J Pharma Pharmaceut Sci. 2012;4(1):239-241.

19. Brindis F, Gonzalez-Andrade M, Gonzalez-Trujano ME, Estrada-Soto S, Villalobos-Molina R. Postprandial glycaemia and inhibition of $\alpha$ glucosidase activity by aqueous extract from Coriandrum sativum. Nat Prod Res. 2014;28(22):2021-5.

20. Jelodar G, Mohsen M, S Sirus. Effect of walnut leaf, coriander and pomegranate on blood glucose and histopathology of pancreas of alloxan induced diabetic rats. Afr J Trad. 2007;4(3):299-305.

21. Rajeshwari U, Iyer S, Bondada A.Comparison of aniseeds and coriander seeds for antidiabetic, hypolipidemic and antioxidant activities. Spatula DD. 2011;1(1):9-16.

22. Waheed A, Miana GA, Ahmad SI, Khan AM. Clinical Investigation of hypoglycemic effect of Coriandrum sativum in Type 2 (NIDDM) diabetic patients. Pakistan J Pharmacol. 2006:23(1):7-11.

23. Gallagher AM, Flatt PR, Duffy G, Abdel-Wahab YH. The effects of traditional antidiabetic plants on in vitro glucose diffusion. Nutr Res. 2003 Mar 1;23(3):413-24.

Cite this article as: Das S, Chaware S, Narkar N, Tilak AV, Raveendran S, Rane P. Antidiabetic activity of Coriandrum sativum in streptozotocin induced diabetic rats. Int J Basic Clin Pharmacol 2019;8:925-9. 